\title{
Selenium balance studies in apparently healthy and housebound elderly people eating self-selected diets
}

\author{
BY VALDA W. BUNKER ${ }^{1}$, MARGARET S. LAWSON ${ }^{2}$, \\ MAUREEN F. STANSFIELD ${ }^{3}$ AND BARBARA E. CLAYTON ${ }^{1}$ \\ ${ }^{1}$ Chemical Pathology and Human Metabolism, and ${ }^{3}$ Geriatric Medicine, Medical Faculty \\ of the University of Southampton, Level D, South Laboratory Block, Southampton \\ General Hospital, Southampton SO9 $4 X Y$ \\ ${ }^{2}$ Department of Applied Chemistry and Life Sciences, The Polytechnic of North London, \\ London $N 87 D B$
}

(Received 8 July 1987 - Accepted 23 September 1987)

\begin{abstract}
1. Metabolic balance studies ( $5 \mathrm{~d}$ ) for Se were conducted in twenty-four apparently healthy elderly people (age 69.6 85.4 years), and twenty housebound subjects (age 69.9-85.1 years) with chronic disease. During the study the subjects lived in their own homes, ate self-selected diets and continued their normal daily activities.

2. Geometric mean daily dietary intakes of the two groups were significantly different $(P<0.01)$, being 819 (range 310-1631) nmol for the healthy and 475 (range 233-1136) nmol for the housebound elderly.

3. Daily intake of Se significantly correlated with balance in both groups. Solution of the regression equations gave theoretical daily requirements of $447 \mathrm{nmol}$ for the healthy and $419 \mathrm{nmol}$ for the housebound subjects. The healthy elderly were in positive balance of $148 \mathrm{nmol} / \mathrm{d}$ for Se and the housebound were in equilibrium with an overall mean retention of $43 \mathrm{nmol} / \mathrm{d}$.

4. Mean levels of Se in blood fractions for the healthy and housebound subjects were significantly different, being 1.65 and $1.40 \mu \mathrm{mol} / 1$ whole blood, 1.45 and $1.21 \mu \mathrm{mol} / 1$ plasma and 5.72 and $5.30 \mathrm{nmol} / \mathrm{g}$ haemoglobin in erythrocytes respectively. There was no difference in the whole-blood glutathione peroxidase $(E C 1.11 .1 .9)$ activities between the two groups.

5. There were ciear differences in Se status between the two groups of elderly people. The cause of the positive balance in the healthy subjects remains unexplained.
\end{abstract}

There is an increasing interest in the possible relation between selenium metabolism and the process of ageing (Csallany et al. 1981). Free radical formation and lipid peroxidation have been proposed as factors which cause membrane damage and accelerate the ageing process (Harman, 1956). Se as a component of glutathione peroxidase (EC 1.11 1.9; GSH-Px) has antioxidant activity and assists in the prevention of the accumulation of lipid peroxides and free radicals (Flohe et al. 1979). There have, however, been relatively few investigations into the Se status of the elderly.

The Se content of some animal tissues is reported to increase with age (Persigehl et al. 1977; Burch et al. 1979). In contrast human erythrocyte Se concentration (Thomson et al. 1977; Miller et al. 1983) and GSH-Px activity (Thomson et al. 1977) appear to fall; such changes may be due to the process of ageing itself, or may reflect an inadequate dietary intake or altered absorption, excretion or distribution of Se in the elderly. There is no firm recommended dietary allowance (RDA) for Se. The existing estimated safe and adequate daily dietary intake (ESADI) of $630-2530 \mathrm{nmol} / \mathrm{d}$ was derived mainly from animal studies (Food and Nutrition Board, 1980). In common with most RDA and ESADI it takes no special account of any effect that ageing or disease may have. Widely differing daily dietary Se intakes have been reported for the elderly, ranging from $2380 \mathrm{nmol}$ in Canada (Gibson et al. 1983) to $300 \mathrm{nmol}$ in Sweden (Abdulla et al. 1979). As the geographical distribution of soil Se content varies considerably (Burk, 1976), interpretation of such reports is difficult.

In order to learn more about the daily intake, retention and excretion of Se in old age 
we have carried out metabolic balance studies on healthy, free-living elderly people eating self-selected diets. In addition, to assess the influence of the commoner chronic diseases of old age on these factors, we have investigated a group of housebound subjects.

\section{METHODS}

\section{Subjects}

The studies were carried out between August 1980 and September 1984. Exact details of the anthropometric characteristics of the subjects have been published elsewhere (Bunker et al. 1987a).

Healthy group. Eleven men (mean age $78 \cdot 2$, range $70 \cdot 1-85 \cdot 2$ years) and thirteen women (mean age $75 \cdot 8$, range 69.6-85.4 years) were included. They were free from any apparent disease, although one woman was subsequently shown to have mild hyperglycaemia. They lived unsupported in their own homes, and purchased and prepared their own food.

Housebound group. Seven men (mean age 78.8, range 69.9-85.1 years) and thirteen women (mean age 78.8 , range $70 \cdot 5-82.9$ years) took part. Subjects were classified as housebound if they were unable to go out unaccompanied. This was generally due to physical infirmity, although two subjects were suffering from severe depression. The participants were suffering from various stable chronic diseases such as arthritis, chronic obstructive pulmonary disease, etc. Individuals known to have hepatic, renal or gastrointestinal disease, malignancies or acute illness were not included. The subjects were receiving various medications including tranquilizers, diuretics and anti-inflamatory drugs as described previously (Bunker et al $1987 \mathrm{~b}$ ). Food was bought by friends, relatives, home help or the subjects themselves when they were taken out. Three men and four women received meals-on-wheels $5 \mathrm{~d} /$ week.

The study was approved by the Joint Ethical Sub-Committee of the Faculty of Medicine of the University of Southampton and Southampton and South West Hampshire District Health Authority.

Metabolic balance studies ( $5 \mathrm{~d}$ ) were carried out as previously described (Bunker et al. $1984 a$ ). This involved the collection of duplicate diets, faeces and urine into plastic containers taking precautions to avoid contamination of the samples. Where a subject received meals-on-wheels two portions were delivered; these were combined and divided, any of the food not eaten being saved separately. It was necessary to spend much time with the subjects, particularly those who were housebound, to ensure reliable collection of samples, but great care was taken not to encourage the subjects to alter their normal eating habits.

Blood samples were obtained from all the healthy and eighteen of the housebound individuals.

\section{Analyses}

Balance material. Samples were analysed by a modified hydride-generation atomic absorption spectrophotometric (HG-AAS) technique used for blood and plasma (Lloyd et al. 1982). Portions of diet $(5 \mathrm{~g})$, faecal $(5 \mathrm{~g})$ and urine $(7.5 \mathrm{~g})$ homogenate were weighed into glass cylinders. Approximately $15 \mathrm{ml} 18 \mathrm{M}$-sulphuric acid-16 M-nitric acid $(1: 1, \mathrm{v} / \mathrm{v})$ solution were added and the samples left to stand for $16 \mathrm{~h}$. The volume was made up to $25 \mathrm{ml}$ with the acid solution and mixed well. Triplicate $1 \mathrm{ml}$ portions were transferred into glass tubes, a $2 \mathrm{ml}$ portion of the acid mixture added and the tubes heated at $150-155^{\circ}$ for $2.5 \mathrm{~h}$. After cooling, $2 \mathrm{ml} 6 \mathrm{M}$-hydrochloric acid was added to the tubes and they were reheated at $95^{\circ}$ for $30 \mathrm{~min}$. The contents were transferred into hydride-generation reaction vessels, diluted to $20 \mathrm{ml}$ and $200 \mu \mathrm{l}$ antifoam reagent added (Antifoam emulsion DB 110A; 
Table 1. Analysis of standard reference materials following digestion with nitric and sulphuric acids

\begin{tabular}{|c|c|c|c|c|c|}
\hline \multirow[b]{2}{*}{ Sample } & \multirow[b]{2}{*}{$\begin{array}{l}\text { No. of } \\
\text { analyses }\end{array}$} & \multicolumn{2}{|c|}{$\begin{array}{l}\text { Value obtained } \\
\text { (nmol/g dry wt) }\end{array}$} & \multicolumn{2}{|c|}{$\begin{array}{l}\text { Certified value* } \\
\text { (nmol/g dry wt) }\end{array}$} \\
\hline & & Mean & $1 \mathrm{SD}$ & Mean & $\begin{array}{c}\text { Estimated } \\
\text { uncertainty }\end{array}$ \\
\hline Bovine liver $1577 \mathrm{a} \dagger$ & 10 & $9 \cdot 13$ & $0 \cdot 22$ & 8.99 & 0.89 \\
\hline Wheat flour $1567 \dagger$ & 2 & $12 \cdot 66$ & - & 13.93 & $2 \cdot 53$ \\
\hline Rice flour $1568 t$ & 2 & $4 \cdot 56$ & - & 5.07 & $1 \cdot 27$ \\
\hline NEA horse kidney $\mathrm{H}-8 \ddagger$ & 2 & $61 \cdot 6$ & - & $59 \cdot 1$ & 3.8 \\
\hline
\end{tabular}

* Certified value converted to SI units.

$\uparrow$ Obtained from National Bureau of Standards, Washington, DC.

$\ddagger$ Obtained from International Atomic Energy Agency, Vienna.

Dow Corning, Glamorgan; $10 \mathrm{ml} / \mathrm{l})$. Standards $(0-2.53 \mu \mathrm{mol} / 1)$ were prepared by taking $100 \mu \mathrm{l}$ volumes, adding $3 \mathrm{ml}$ of the acid mixture and proceeding as for the test samples.

Hydrogen selenide vapour was produced by adding $6 \mathrm{ml}$ sodium tetrahydroborate (III) $(0.16 \mathrm{M}(60 \mathrm{~g} / 1)$ in $0.025 \mathrm{M}$-sodium hydroxide solution) to the reaction vessel. Se concentration was measured using a Perkin Elmer atomic absorption spectrophotometer (model 2380) with an electrode-less discharge lamp and a mercury-hydride system (MHS 20). The following instrumental conditions were used: tube temperature $950^{\circ}$, purge $I$ (argon) $38 \mathrm{~s}$, reaction time $10 \mathrm{~s}$, purge II (argon) $25 \mathrm{~s}$. Integrated peak area was measured with a read time of $19 \mathrm{~s}$.

It has been suggested (Janghorbani et al. 1982; Neve et al. 1982) that the inclusion of perchloric acid in the digestion procedure is essential for the complete decomposition of the organic matrix and conversion of organoselenium to Se IV. We have found (Bunker \& Delves, 1987) no difference in the digestion efficiencies of a nitric-sulphuric acid mixture and a nitric-sulphuric-perchloric acid mixture for dietary faecal and urinary samples subsequent to analysis by HG-AAS. The attendant potential hazards associated with the use of perchloric acid and the need for special venting facilities makes the avoidance of this acid desirable.

Four different standard reference materials were analysed by the method described and the results are given in Table 1 . Mean within-batch precision of $3 \cdot 0,3 \cdot 1$ and $2.5 \%$ and mean recoveries of Se added to the acid chemical homogenate of 98,103 and $102 \%$ were obtained for the analysis of ten samples of urinary, dietary and faecal homogenates respectively.

The dietary samples were also analysed for nitrogen (semi-automated Kjeldahl; Tecator, Bristol) and gross energy (bomb calorimeter; Gallenkamp, London). The protein content was calculated assuming a $160 \mathrm{~g} \mathrm{~N} / \mathrm{kg}$ protein concentration and metabolizable energy was calculated using the formula of Miller \& Payne (1959). These results have been reported previously (Bunker et al. 1987a).

\section{Blood samples}

Haematological analyses were carried out using a Coulter-counter model $\mathrm{S}+4$. Whole blood and plasma samples were analysed for Se by the method of Lloyd et al. (1982). Erythrocyte Se concentration was calculated from the difference between the concentration in whole blood and plasma, taking the packed cell volume into account. GSH-Px activity was measured in whole blood by the method of Beutler (1979), using $t$-butyl hydroperoxide as a substrate. 
Table 2. Daily dietary selenium intake in elderly healthy and housebound men and women

(Geometric means, with arithmetic means in parentheses, and $95 \%$ confidence interval $(95 \% \mathrm{CI})$ )

\begin{tabular}{|c|c|c|c|c|c|c|c|}
\hline & \multirow[b]{3}{*}{$n$} & \multicolumn{6}{|c|}{ Se intake } \\
\hline & & \multicolumn{2}{|c|}{$\mathrm{nmol} / \mathrm{d}$} & \multicolumn{2}{|c|}{$\mathrm{nmol} / \mathrm{kg}$ body-wt per $\mathrm{d}$} & \multicolumn{2}{|c|}{$\mathrm{nmol} / 10 \mathrm{MJ}$} \\
\hline & & Mean & $95 \% \mathrm{CI}$ & Mean & $95 \% \mathrm{Cl}$ & Mean & $95 \% \mathrm{Cl}$ \\
\hline \multicolumn{8}{|l|}{ Healthy: } \\
\hline Men & 11 & $879(895)$ & $805-959$ & $12.6(12.9)$ & $11 \cdot 5-13 \cdot 9$ & $973(984)$ & $909-1041$ \\
\hline Women & 13 & $773(859)$ & $626-953$ & $12.2(13.7)$ & $9 \cdot 9-15 \cdot 0$ & $1125(1223)$ & $939-1349$ \\
\hline All & 24 & $819(876)$ & $695-966$ & $12.4(13.4)$ & $10 \cdot 5-14 \cdot 6$ & $1053(1114)$ & $914-1213$ \\
\hline \multicolumn{8}{|c|}{ Housebound: } \\
\hline Men & 7 & $484(512)$ & $411-570$ & $7 \cdot 2(7 \cdot 5)$ & $6 \cdot 4-8 \cdot 2$ & $760(795)$ & $651-889$ \\
\hline Women & 13 & $470(513)$ & $385-575$ & $7 \cdot 7(8 \cdot 3)$ & $6 \cdot 3-9 \cdot 4$ & $951(1045)$ & $772-1172$ \\
\hline All & 20 & $475(513)$ & $395-571$ & $7 \cdot 5(8 \cdot 0)$ & $6 \cdot 3-8.9$ & $879(958)$ & $724-1068$ \\
\hline \multicolumn{8}{|c|}{ Probability values for the independent effect of sex and health: } \\
\hline Sex & - & NS & - & NS & - & NS & - \\
\hline Health & - & $P<0.001$ & - & $P<0.001$ & - & $P<0.01$ & - \\
\hline
\end{tabular}

NS, not significant.

\section{Statistical analysis}

Each group of results was examined to assess their closeness to a normal distribution. All values relating to blood analyses approximated such a distribution; those for Se intake, urinary, faecal and total excretion were positively skewed, and were therefore logarithmically transformed to achieve approximate normality. The log-transformed mean and standard deviation were used to calculate the geometric mean and $95 \%$ confidence interval $(95 \% \mathrm{CI})$. To facilitate comparison with other published work, the arithmetic mean values, where appropriate, were calculated. Multiple regression analysis was used to assess the effects of health, sex and body-weight on the results. Association between variables was determined using Pearson's correlation coefficient, a paired $t$ test was used to assess the significance of the retention values obtained and an unpaired $t$ test used to compare the Se concentration in the blood fractions and the whole blood GSH-Px activity between the two groups of elderly (Armitage, 1971).

\section{RESULTS}

Table 2 gives the results of daily Se intake for both groups of men and women. The daily dietary Se intake correlated with that of protein (healthy $r 0.62, P<0.01$; housebound $r 0.41, P<0.05$ ). In the healthy group, only two women and one man had intakes below the lower level of the ESADI of $630 \mathrm{nmol}$, while eleven women and five men in the housebound group consumed less than this amount. The meals-on-wheels provided a mean level of 166 (95\% CI 136-196) nmol, of which 139 (95\% CI 94-184) nmol were consumed. This was equivalent to $38 \%$ of the total daily Se intake of the seven recipients.

The results of the balance studies are given in Table 3 and Fig. 1. The healthy were in positive balance of $148 \mathrm{nmol}$, a value which significantly differed from zero $(t 4.52)$. The housebound were in equilibrium $(t 1.41)$ for Se, with a mean retention of $43 \mathrm{nmol}$. There was no difference in the intake, excretion or retention of Se for men or women in either group. Se retention was significantly correlated with dietary intake (healthy $r 0.66$, $P<0.001$; housebound $r 0.75, P<0.001$ ) as shown in Fig. 2 . Balance was not affected by 
Table 3. Daily intake, excretion and retention of selenium (nmol/d) in healthy and housebound men and women

(Mean values and $95 \%$ confidence interval $(95 \% \mathrm{CI})$ )

\begin{tabular}{|c|c|c|c|c|c|c|c|}
\hline & \multirow[b]{2}{*}{$n$} & \multicolumn{2}{|c|}{ Intake } & \multicolumn{2}{|c|}{$\begin{array}{c}\text { Total } \\
\text { excretion }\end{array}$} & \multicolumn{2}{|c|}{$\begin{array}{l}\text { Urinary } \\
\text { excretion }\end{array}$} \\
\hline & & Mean & $95 \% \mathrm{CI}$ & Mean & $95 \% \mathrm{CI}$ & Mean & $95 \% \mathrm{CI}$ \\
\hline \multicolumn{8}{|l|}{ Healthy: } \\
\hline Men & 11 & 878 & $805-959$ & 721 & $661-785$ & 368 & $327-415$ \\
\hline Women & 13 & 773 & $626-953$ & 667 & $559-796$ & 334 & $286-389$ \\
\hline All & 24 & 819 & $695-966$ & 691 & $600-796$ & 349 & $305-401$ \\
\hline \multicolumn{8}{|c|}{ Housebound: } \\
\hline Men & 11 & 484 & $411-570$ & 505 & $450-566$ & 244 & $207-288$ \\
\hline Women & 13 & 470 & $385-575$ & 417 & $349-498$ & 200 & $165-243$ \\
\hline \multirow[t]{3}{*}{ All } & 20 & 475 & $395-571$ & 446 & 379.524 & 214 & $178-258$ \\
\hline & & \multicolumn{2}{|c|}{$\begin{array}{c}\text { Faecal } \\
\text { excretion }\end{array}$} & \multicolumn{2}{|c|}{$\begin{array}{c}\text { Apparent } \\
\text { absorption }\end{array}$} & \multicolumn{2}{|c|}{$\begin{array}{c}\text { Net } \\
\text { retention }\end{array}$} \\
\hline & $n$ & Mean & $95 \% \mathrm{CI}$ & Mean & $95 \% \mathrm{CI}$ & Mean & $95 \% \mathrm{CI}$ \\
\hline \multicolumn{8}{|l|}{ Healthy: } \\
\hline Men & 11 & 334 & $288-388$ & 543 & $473-613$ & 161 & $93-229$ \\
\hline Women & 13 & 324 & $258 \quad 407$ & 492 & $386-598$ & 137 & $67-207$ \\
\hline All & 24 & 329 & $271-398$ & 515 & $426-605$ & 148 & $80-216$ \\
\hline \multicolumn{8}{|c|}{ Housebound: } \\
\hline Men & 11 & 239 & $196-292$ & 251 & $186-316$ & -5 & $-65-54$ \\
\hline Women & 13 & 211 & $174-257$ & 285 & $202-368$ & 69 & 4-134 \\
\hline All & 20 & 221 & $182-268$ & 273 & $197-349$ & 43 & $-21-107$ \\
\hline
\end{tabular}

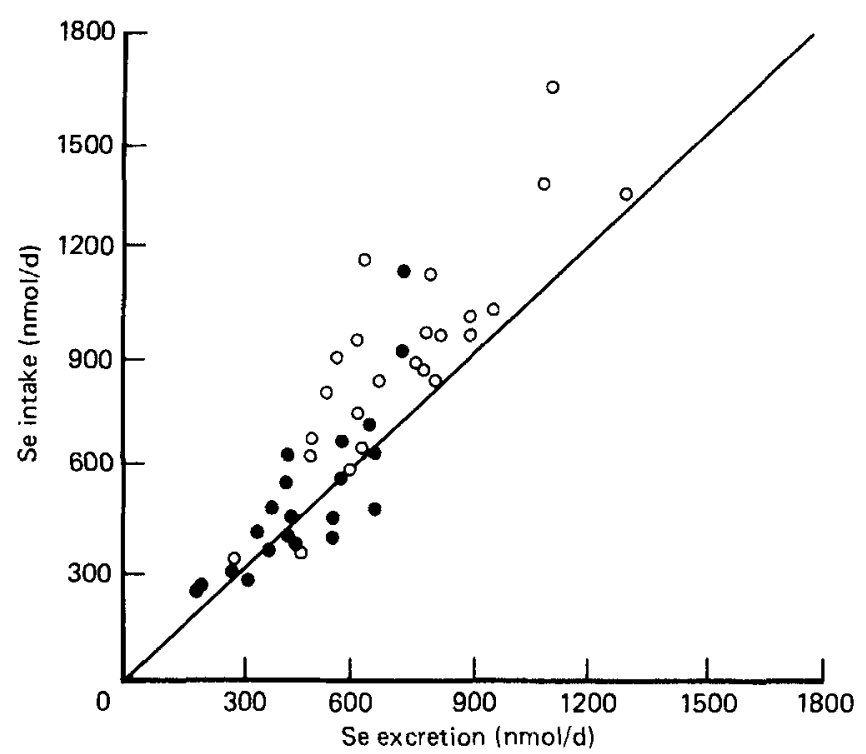

Fig. 1. Daily selenium balance in healthy $(O)$ and housebound (O) elderly. The line of equality $(y=x)$ is shown. 


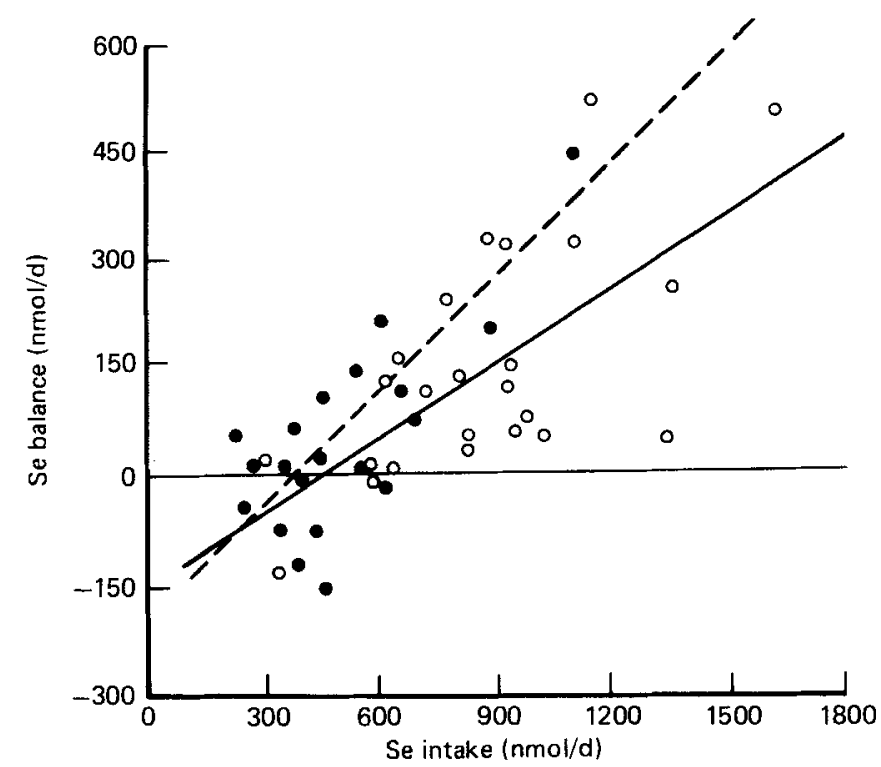

Fig. 2. Relation between selenium intake and Se balance in healthy $(O)$ and housebound $(O)$ elderly people. (-), (--), Regression lines for healthy and housebound elderly respectively.

Table 4. Selenium concentration in blood and plasma and whole-blood glutathione peroxidase (EC 1.11.1.9) activity in healthy and housebound elderly and younger individuals

(Arithmetic mean and $95 \% \mathrm{CI}$ )

\begin{tabular}{|c|c|c|c|c|c|c|}
\hline & \multicolumn{2}{|c|}{$\begin{array}{l}\text { Healthy elderly } \\
\qquad(n 24)\end{array}$} & \multicolumn{2}{|c|}{$\begin{array}{l}\text { Housebound elderly } \\
\qquad(n \text { 18) }\end{array}$} & \multicolumn{2}{|c|}{$\begin{array}{c}\text { Younger adults } \dagger \\
(n \text { 338) }\end{array}$} \\
\hline & Mean & $95 \% \mathrm{CI}$ & Mean & $95 \% \mathrm{CI}$ & Mean & $95 \% \mathrm{Cl}$ \\
\hline Whole-blood Se $(\mu \mathrm{mol} / \mathrm{l})$ & $1 \cdot 65$ & $1.57-1 \cdot 73$ & $1 \cdot 40^{* * *}$ & $1 \cdot 28-1 \cdot 52$ & $1 \cdot 75$ & $1 \cdot 72-1 \cdot 78$ \\
\hline Plasma Se $(\mu \mathrm{mol} / 1)$ & 1.45 & {$[\cdot 38-1 \cdot 53$} & $1 \cdot 21 * *$ & $1 \cdot 08-1 \cdot 35$ & 1.47 & $1 \cdot 45-1 \cdot 49$ \\
\hline Erythrocyte Se (nmol/g Hb) & $5 \cdot 72$ & $5 \cdot 54-5 \cdot 91$ & $5 \cdot 30^{*}$ & $4 \cdot 99-5 \cdot 61$ & $6 \cdot 25$ & $6 \cdot 13-6 \cdot 37$ \\
\hline $\begin{array}{l}\text { Whole-blood glutathione } \\
\text { peroxidase }(\mathrm{U} / \mathrm{g} \mathrm{Hb})\end{array}$ & 21 & $19-23$ & 19 & 1722 & $19 \cdot 6$ & $19 \cdot 120 \cdot 1$ \\
\hline
\end{tabular}

$\mathrm{Hb}$, haemoglobin.

Mean values were significantly different from those of the healthy elderly: ${ }^{*} P<0.05,{ }^{* *} P<0 \cdot 01,{ }^{* * *} P<0.001$

$\dagger$ Published values of Lloyd et al. (1983) converted to SI units.

body-weight. Analysis of covariance showed that a single straight line could be used to describe the values for men and women as there was no significant difference between the slopes. Statistical analysis also showed that the slopes obtained for the healthy and housebound groups were similar. The following equations were derived to describe the association between Se intake (nmol/d) and balance (nmol/d) for healthy and housebound elderly respectively: Se balance $=0.34$ intake -152 and Se balance $=0.47$ intake -197 . Expressed in terms of body-weight (nmol/ $\mathrm{kg}$ per $\mathrm{d}$ ) the following equations were obtained for the healthy and housebound subjects respectively: Se balance $=0.39$ intake -2.76 and Se balance $=0.53$ intake -3.55 . Se retention did not correlate with any other measurements of Se status. 
Table 4 gives the results of the analyses of Se concentration in whole blood, erythrocytes and plasma and GSH-Px activity in blood. There was no difference in any of the values obtained between men and women and therefore the values have been combined. There was no correlation between GSH-Px activity and any measurement of Se status.

\section{DISCUSSION}

The mean (geometric) daily Se intake of $819 \mathrm{nmol}$ in the healthy elderly exceeded the lower level of the ESADI of $630-2530 \mathrm{nmol} / \mathrm{d}$ (Food and Nutrition Board, 1980) and was similar to the average estimated intake for this country of $760 \mathrm{nmol}$ (Thorn et al. 1978). The value was lower than the mean values of 1380 and $1190 \mathrm{nmol} / \mathrm{d}$ calculated for elderly people eating self-selected diets in Canada (Gibson et al. 1983) and America (Lane et al. 1983) respectively, but is similar to the median intake of $881 \mathrm{nmol}$ determined by analysis for the diets of elderly Canadian women (Gibson et al. 1985). The dietary Se intake of our healthy subjects was considerably higher than the median value of $304 \mathrm{nmol} / \mathrm{d}$ found by duplicate diet analysis for a group of Swedish pensioners (Abdulla et al. 1979). It must be borne in mind, however, when making such comparisons, that we have reported geometric mean intakes whilst other authors have given arithmetic mean or median values. Additionally, as a result of the geographical distribution of soil Se levels, the dietary intake of this element varies greatly in different parts of the world (Burk, 1976).

The mean Se intake of the housebound subjects of $475 \mathrm{nmol} / \mathrm{d}$ was only $58 \%$ of that found in the healthy people. Differences in energy consumption do not entirely account for this finding. The housebound subjects consumed a significantly-less Se-dense diet than the healthy elderly $(879$ v. $1053 \mathrm{nmol} / 10 \mathrm{MJ} ; P<0.01)$. This observation contrasts with the fact that the densities of the diets eaten by both groups of elderly were comparable with respect to several nutrients, including protein (Bunker et al. 1987a), zinc, copper (Bunker et al. 1984a, 1987 b), calcium, phosphorus and magnesium (Bunker et al. 1988). In assessing the dietary intake of $\mathrm{Se}$ it is essential to consider the contribution that different food groups make to the total intake. Thorn et al. (1978), in a study of diet samples collected in 1974, reported that half the $\mathrm{Se}$ in the average British diet was derived from cereals and cereal products, with meat and fish providing another $40 \%$. Since this report there has been a reduction in the import of wheat from Canada and the USA (Ministry of Agriculture, Fisheries and Food (MAFF), personal communication). The average Se concentration of wheat obtained from North America is at least ten times greater than that of homeproduced wheat (Thorn et al. 1978). Consequently the proportion of American wheat included in milling has a profound influence on the Se content of flour. The duplicate-diet collections for the healthy subjects were carried out between August 1980 and July 1982, while those for the housebound elderly were obtained between July 1983 and September 1984. During this time the contribution of imported wheat from North America to the total amount of wheat milled in this country decreased from approximately $35 \%$ in 1980 to approximately $17 \%$ in 1984 (MAFF, personal communication). This fact may go some way to explain the differences in the Se densities of the diets eaten by the two groups of elderly.

The healthy elderly were in positive balance of $148 \mathrm{nmol}$ for Se. This high apparent positive retention is difficult to explain. It is unlikely that inaccuracies have occurred in the measurement of intake or excretion. The precision and accuracy of the analytical method have been validated, and good agreement was obtained between the analysed and certified values for a range of different organic quality control materials. Analysis of the same samples has shown these subjects to be in equilibrium for $\mathrm{N}, \mathrm{Zn}$ and $\mathrm{Cu}$, iron and chromium (Bunker et al. $1984 a, b, c, 1987 a$ ). The balance values do not, however, take 
account of losses via perspiration or expired air. Studies from New Zealand using ${ }^{75} \mathrm{Se}-$ labelled selenite (Thomson \& Stewart, 1974) and selenomethionine (Griffiths et al. 1976) found dermal and respiratory losses to be negligible. Actual measurements of sweat (Levander et al. 1981) and skin (Molin \& Wester, 1976) Se content suggest that daily losses from each are less than $13 \mathrm{nmol}$.

Some workers (Janghorbani et al. 1982; Neve et al. 1982) believe that the trimethylselonium ion, which may be a major excretory form of Se in urine, is extremely difficult to digest without the use of perchloric acid. Other authors (Reamer \& Veillon, $1981,1983 a, b)$ do not agree with this suggestion and we (Bunker \& Delves, 1987) have found no difference in urinary Se concentration determined with and without the use of perchloric acid. The method described here has also been used to analyse urine in an International Union of Pure and Applied Chemistry (IUPAC) inter-laboratory study. The mean value obtained was within the range of reported observations from other laboratories and agreed particularly well with those results derived using neutron-activation analysis with radiochemical separation and isotope-dilution mass spectrometry following acid digestion.

To date there is only one report in the literature of balance studies for Se being carried out in the elderly (Stead et al. 1985). Unfortunately details relating to study design and analytical techniques were minimal. Five of the six men studied did not live independently in the community, and subjects were admitted to the metabolic unit only $24 \mathrm{~h}$ before the commencement of the study. The subjects consumed a mean of $760 \mathrm{nmol} \mathrm{Se} / \mathrm{d}$ and were in positive balance to the extent of $282 \mathrm{nmol}$. This value represented a retention of $37 \%$ of the dietary intake compared with $14 \%$ by the subjects in the present study. Obviously the six men studied were not in equilibrium with their hospital diets and the validity of the findings is questionable. Levander \& Morris (1984) have carried out balance studies on young North American adults eating self-selected diets providing an average of $1025 \mathrm{nmol}$ $\mathrm{Se} / \mathrm{d}$. The subjects were in positive balance of $129 \mathrm{nmol} / \mathrm{d}$, which represented $13 \%$ of their daily intake. Two other studies carried out on subjects eating self-selected diets are also of interest. Four New Zealand women have been shown (Stewart et al. 1978) to be in equilibrium for Se with an average daily intake of $306 \mathrm{nmol}$, while ten Chinese men were found to be in positive balance to the extent of $23 \mathrm{nmol}$, with a mean daily intake of only $114 \mathrm{nmol}$ (Luo et al. 1985). It is important to note that perchloric acid digestion was used in the sample preparation for the three studies (Stewart et al. 1978; Levander \& Morris, 1984; Luo et al. 1985) on younger people. Yet in two of them (Levander \& Morris, 1984; Luo et al. 1985) the subjects were in overall positive balance. The reason for these results and the positive balance of the subjects in the present study remains unexplained.

The housebound subjects were in equilibrium for Se with a mean retention of $43 \mathrm{nmol}$. This finding contrasts with the overall negative $\mathrm{N}, \mathrm{Zn}$ and $\mathrm{Cu}$ (Bunker et al. 1987a,b) balances reported by us for this group. The housebound appear to be in balance for Se but their status is quite different from that of the healthy elderly.

Absorption of Se was similar in the healthy and housebound subjects (mean $0.57(95 \%$ CI $0.53-0.62)$ v. $0.50(95 \%$ CI $0.43-0.57))$. These values are comparable to those of 0.64 , 0.55 and 0.57 found for younger subjects eating self-selected diets in North America (Levander \& Morris, 1984), New Zealand (Stewart et al. 1978) and China (Luo et al. 1985) respectively. Urinary Se excretion accounted for 50 and $48 \%$ of the total excretion in the healthy and housebound subjects respectively, a percentage similar to that found in the aforementioned studies.

There was a highly significant correlation between Se intake and retention in both groups of elderly people. Solution of the appropriate regression equations provided theoretical daily requirements of 447 and $419 \mathrm{nmol}$ Se to maintain balance in healthy and housebound subjects respectively. These values are less than the values of 1013 and $722 \mathrm{nmol}$ reported 
by Levander \& Morris (1984) for young men and women, but greater than the level of $304 \mathrm{nmol}$ found by Stewart et al. (1978) for young women in New Zealand. This reinforces the suggestion of Levander \& Morris (1984) that Se requirement is a function of previous dietary intake. The same authors, in explaining an observed difference between the requirement for men and women, speculated that requirement is also dependent on lean body mass (LBM). We found no difference between the needs of men and women. Men lose LBM more rapidly with age than women, and therefore it is possible that the differences between the sexes are less marked in the elderly. Solution of the weight-adjusted regression equations gave values for theoretical daily requirement of 7.08 and $6.70 \mathrm{nmol} / \mathrm{kg}$ per $\mathrm{d}$ for the healthy and housebound people respectively.

The level of Se found in the whole blood and erythrocytes of the healthy elderly was slightly lower than the values reported by this laboratory (Lloyd et al. 1983) for younger adults. Since the studies of the healthy elderly and younger subjects were carried out simultaneously, a comparison of the two groups is valid. There was no difference between the two groups in the plasma Se concentration or the whole-blood GSH-Px activity. A fall in erythrocyte Se concentration with age has been reported previously by some authors (Thomson et al. 1977; Miller et al. 1983) while others found that plasma but not erythrocyte levels fell with age (Verlinden et al. 1983). Thomson et al. (1977) also reported a concomitant fall in plasma Se levels and also erythrocyte GSH-Px activity. Certain human and animal tissues are reported to accumulate Se with progressive age (Persigehl et al. 1977; Burch et al. 1979), and an increase in liver GSH-Px activity per unit protein with age has also been shown in normal human liver (Corrocher et al. 1980). It is possible that a redistribution of Se from the erythrocyte to other tissues may occur with ageing.

The housebound elderly had significantly lower whole blood, erythrocyte and plasma Se concentrations than did the healthy subjects. This can probably be attributed to the lower Se consumption in this group. There was, however, no significant difference in whole blood GSH-Px activities between the two groups.

There were clear differences between the healthy and housebound groups. The former were in positive balance for reasons which remain unexplained, and the latter were in equilibrium. The mean dietary intake in the housebound elderly of $475 \mathrm{nmol}$ was marginally in excess of the theoretical requirement of $419 \mathrm{nmol}$, but failed to reach the ESADI (Food and Nutrition Board, 1980). Plasma, whole blood and erythrocyte Se concentrations were lower than found in the healthy people, although whole blood GSHPx activity was unaffected. Although we cannot prove that the Se status in this group was suboptimal, it is apparent that it was different from that of healthy elderly people.

The authors thank our volunteers who participated so willingly, their general practitioners for giving us permission to study their patients and Alison Mills for information regarding wheat imports. Financial support from The Foundation for Age Research, The Wessex Regional Health Authority and The Wessex Medical School Trust is gratefully acknowledged.

\section{REFERENCES}

Abdulla, M., Kolar, K. \& Svensson, S. (1979). Scandanavian Journal of Gastroenterology 14 Suppl. 52, $181-184$.

Armitage, P. (1971). Statistical Methods in Medical Research. Oxford: Blackwell Scientific Publications. Beutler, E. (1979). A Manual of Biochemical Methods, 2nd ed, pp. 71-73. New York: Grune and Stratton. Bunker, V. W. \& Delves, H. T. (1987). Analytica Chimica Acta 201, 331-334.

Bunker, V. W., Hinks, L. J., Lawson, M. S. \& Clayton, B. E. (1984a). American Journal of Clinical Nutrition 40, 1096-1102.

Bunker, V. W., Lawson, M. S. \& Clayton, B. E. (1984b). Journal of Clinical Pathology 37, 1353-1357.

Bunker, V. W., Lawson, M. S., Delves, H. T. \& Clayton, B. E. (1984c). American Journal of Clinical Nutrition 39. $797-802$. 
Bunker, V. W., Lawson, M. S., Stansfield, M. F. \& Clayton, B. E. (1987a). British Journal of Nutrition 57, 211-221.

Bunker, V. W., Lawson, M. S., Stansfield, M. F. \& Clayton, B. E. (1987 b). American Journal of Clinical Nutrition 46, 353-359.

Bunker, V. W., Lawson, M. S., Stansfield, M. F. \& Clayton, B. E. (1988). Journal of Gerontology (In the Press).

Burch, R. E., Sullivan, J. F., Jetton, M. M. \& Hahn, H. K. J. (1979). Age 2, 103-107.

Burk, R. F. (1976). In Trace Elements in Human Health and Disease, pp. 105-133 [A. S. Prasad and D. Oberleas, editors). New York: Academic Press.

Corrocher, R., Casaril, M., Guidi, C., Cabrielli, B., Mialto, O. \& De Sandre, G. (1980). Scandanavian Journal of Gastroenterology 15, 781-786.

Csallany, A. S., Zaspel, B. J. \& Ayaz, K. L. (1981). In Selenium in Biology and Medicine, pp. 118-131 [J. E. Spallholz, J. L. Martin and H. E. Ganther, editors]. Westpoint, CT: AVI Publishing Co.

Flohe, L., Gunzler, W. A. \& Loschen, G. (1979). In Trace Elements in Health and Disease, pp. 263-286 [N. Kharasch, editor]. New York: Raven Press.

Food and Nutrition Board (1980). Recommended Dietary Allowances, 9th revised ed. Washington, DC: National Academy of Sciences.

Gibson, R. S., Anderson, B. M. \& Sabry, J. H. (1983). Journal of the American Dietetic Association 82, $246-250$

Gibson, R. S., Martinez, O. B. \& MacDonald, A. C. (1985). Journal of Gerontology 40, 296-302.

Griffiths, N. M., Stewart, R. D. H. \& Robinson, M. F. (1976). British Journal of Nutrition 35, 373-382.

Harman, D. (1956). Journal of Gerontology 11, 298-300.

Janghorbani, M., Ting, B. T. G., Nahapetian, A. \& Young, V. R. (1982). Analytical Chemistry 54, $1188-1190$.

Lane, H. W., Warren, D. C., Taylor, B. J. \& Stool, E. (1983). Proceedings of the Society for Experimental Biology and Medicine 173, 87-95.

Levander, O. A. \& Morris, V. C. (1984). American Journal of Clinical Nutrition 39, 809-815.

Levander, O. A., Sutherland, B., Morris, V. C. \& King, J. C. (1981). In Selenitum in Biology and Medicine, pp. 256-258 [J. E. Spallholz, J. L. Martin and H. E. Ganther, editors]. Westpoint, CT: AVI Publishing Co.

Lloyd, B., Holt, P. \& Delves, H. T. (1982). Analyst 107, 927-933.

Lloyd, B., Lloyd, R. S. \& Clayton, B. E. (1983). Journal of Epidemiology and Community Health 37, $213-217$.

Luo, X., Wei, H., Yang, C., Xing, J., Qiao, C., Feng, Y., Liu, J., Liu, Z., Wu, Q., Liu, Y., Stoecker, B. J., Spallholz, J. E. \& Yang, S. P. (1985). American Journal of Clinical Nutrition 42, 31-37.

Miller, D. S. \& Payne, P. R. (1959). British Journal of Nutrition 13, 501-508.

Miller, L., Mills, B. J., Blotcky, A. J. \& Lindeman, R. D. (1983). Journal of the American College of Nutrition 4, 331-341.

Molin, L. \& Wester, P. O. (1976). Scandanavian Journal of Clinical and Laboratory Investigation 36, 679-682.

Neve, J., Hanocq, M., Molle, L. \& Lefebvre, G. (1982). Analyst 107, 934-941.

Persigehl, M., Schicha, H., Kasperek, K. \& Klein, H. J. (1977). Beitrage zur Patholozie 161, 209-220.

Reamer, D. C. \& Veillon, C. (1981). Analytical Chemistry 53, 1192-1195.

Reamer, D. C. \& Veillon, C. (1983a). Analytical Chemistry 55, 1605-1606.

Reamer, D. C. \& Veillon, C. (1983 b). Journal of Nutrition 113, 786-792.

Stead, N. W., Leonard, S. \& Carroll, R. (1985). American Journal of Medical Science 290, 228-233.

Stewart, R. D. H., Griffiths, N. M., Thomson, C. D. \& Robinson, M. F. (1978). British Journal of Nutrition 40 , 45-54.

Thomson, C. D., Rea, H. M., Robinson, M. F. \& Chapman, O. W. (1977). Proceedings of the University of Otago Medical School 55, 18-19.

Thomson, C. D. \& Stewart, R. D. H. (1974). British Journal of Nutrition 32, 47-57.

Thorn, J., Robertson, J., Buss, D. H. \& Bunton, N. G. (1978). British Journal of Nutrition 39, $391-396$.

Verlinden, M., van Sprundel, M., Van der Auwera, J. C. \& Eylenbosch, W. J. (1983). Biological Trace Element Research 5, 103-113. 